\title{
Paradigma Pendidikan Pembebasan Paulo Freire Dalam Konteks Pendidikan Agama Islam
}

\author{
Aridlah Sendy Robikhah \\ UIN Sunan Kalijaga Yogyakarta, Indonesia \\ aridlahsendy@gmail.com
}

\begin{abstract}
Abstrak:
Pendidikan cenderung mengabaikan beberapa nilai pembebasan. Manusia dianggap seperti mesin mekanik yang harus dipatuhi dari sistem. Tidak ada kebebasan berpikir, kebebasan bertindak, kebebasan dalam berekspresi dan kebebasan untuk memberikan ide. Paulo Freire, ilmuwan pendidikan memberikan beberapa ilustrasi alternatif untuk pedagogi pembebasan. Penelitian ini menggunakan metode dokumenter. Penulis mengumpulkan beberapa sumber buku, lalu mengklasifikasikan berdasarkan kelompok (biografi, teori Paulo Freire dan pedagogi pembebasan dalam pendidikan Islam). Studi ini menemukan bahwa pedagogi pembebasan dalam hal ini berarti memiliki kesadaran tentang pendidikan dan kehidupan sehari-hari, sehingga apa yang siswa dapatkan dari guru dapat berguna untuk menghadapi masalah mereka. Mempelajari dan membaca buku perlu konsentrasi, karena menurut teori Paulo Freire, esensi studi adalah menciptakan kembali, menciptakan kembali, dan menulis ulang. Siswa harus tahu apa tujuan pembelajaran di setiap tema, karena pedagogi tidak seperti sistem perbankan, siswa tidak seperti kotak kosong. Siswa adalah manusia yang memiliki bakat dan kemampuan, jadi ini adalah tugas guru untuk menemukan dan mengembangkan kemampuan siswa. Ketika teori ini diterapkan dalam Studi Islam, penyelesaian beberapa masalah siswa, masih harus menghubungkan ke Alquran dan Hadis dengan prinsip gerakan ganda.
\end{abstract}

Kata kunci: Paulo Freire, Kebebasan, Pedagogig, Pembebasan Pedagogig

\footnotetext{
Abstract:

Education disposed ignoring some liberation values. Human considered like a mechanic machine that must be obey from the system. There is no liberation of thinking, liberation of
} 
act, liberation in expression and liberation for giving ideas. Paulo Freire, educational scientist gives some alternative illustrations for liberation pedagogy. This study applied a documentary method. Writer collect some book resources, then classify based on groups (biography, Paulo Freire's theory and liberation pedagogy in Islamic education). This study found that liberation pedagogy in this case means to have awareness about education and daily life, so what student gets from teacher can be useful for facing their problems. Studying and reading books needs concentration, because according to Paulo Freire's theory, the essences of study are reinventing, recreating and rewriting. Student must know what learning goals in each themes, because pedagogy is not like banking system, students are not like an empty box. Students are human that have talent and capability, so this is teacher's assignment to find and develop student's ability. When this theory applied in Islamic Study, the solve of some student problems, still have to link to Alquran and Hadis with a double movement principle.

Keyword: Paulo Freire, Liberation, Pedagogy, Liberation Pedagogy

\section{Pendahuluan}

Perkembangan ilmu pengetahuan dan teknologi merupakan buah dari kebebasan. Sebuah kebabasan memiliki arti melepaskan jeratan dari berbagai belenggu. Pendidikan mengajarkan murid untuk dapat menyesuaikan diri dengan lingkungannya, oleh karena itu pendidikan harusnya melihat tentang kebutuhan murid, bukan malah menyamaratakan cara berfikir mereka. Misalnya, diberikan kebebasan dalam menilai sesuai dengan sudut pandangnya, kemudian dilanjutkan dengan dialog bersama gurunya. Dengan demikian secara perlahan akan mengerti apa yang seharusnya ia lakukan. Kebernaian-keberanian dalam menyampaikan pendapat seperti inilah salah satu prinsip dari kebebasan yang akan melatih murid untuk bertanggung jawab dan tidak terjerat dengan asumsi-asumsi pendidikan yang sudah tersetting. Selanjutnya, penulis akan menguraikan bagaimana teori-teori Paulo Freire tentang pendidikan pembebasan dan jawaban alternatif Paulo Freire untuk menangani pendidikan yang terbelenggu serta pendidikan pembebasan apabila dikaitkan dengan Pendidikan Agama Islam

\section{Review Literatur}

Siswanto menulis dengan judul Pendidikan Sebagai Paradigma Pembebasan (Telaah Filsafat Pendidikan Paulo Freire). Siswanto menuliskan bahwa Paulo Freire menawarkan model pendidikan baru yaitu model pendidikan pembebasan. Pembebasan sendiri bermakna transformasi sebuah sistem realitas yang saling terkait dan kompleks, serta reformasi beberapa individu untuk mereduksi berbagai konsekuensi negatif dari sebuah perilaku. Langkah utama 
yang menentukan dalam upaya pendidikan pembebasannya adalah penyadaran yang melekat dan merupakan proses inti dalam keseluruhan proses pendidikan itu sendiri. Untuk mewujudkan hal tersebut, kebiasaan pendidikan deskriptif diharapkan digeser ke arah pendidikan dialogik-transformatif, agar pendidikan tidak dirasakan sebagai pendidikan yang membelenggu. Pendidikan diharapkan dapat meghasilkan perubahan, baik perubaha dalam kualitas berpikir, kualitas pribadi, kualitas sosial, kualitas kemandirian dan kualitas kemasyarakatannya.

Selanjutnya, tulisan dengan judul Pendidikan Pembebasan (Telaah Terhadap Pemikiran Paulo Freire) karya Muh. Idris. Dalam tulisan ini Muh. Idris lebih concern kepada hakekat tujuan pendidikan yang membebaskan menurut Paulo Freire. Tujuan pendidikan yang dimaksud adalah fitrah yang sejalan dengan hukum alam. Setiap orang berupaya menjadi manusia sejatiyang harus terwujud melalui dunia pendidikan. Lembaga pendidikan sebagai wahana pengembangan ilmu dalam arti luas. Ilmu dapat berkembang dengan pesat dalam dunia pendidikan $\mathrm{s}=$ dengan beragam perbedaan baik itu intidisipliner, multidisipliner dan trandisipliner dalam kerangka pendidikan. Kekayaan keilmuan tersebut lahir dari kebebasan dan pembebasan berpikir. Kebebasan berpikir merupakan suatu nilai yang sangat dirindukan dan didambakan setiap insan pemikir. Sketsa pemikiran Freire mencoba mengintegrasikan nilai-nilai kemanusiaan yang bebas dalam pendidikan. Nilai kemanusiaan yang bebas adalah yang bernapaskan kreativitas berpikir dalam membangun komunikasi yang positif, inovatif, konstruktif, guna melahirkan amal saleh. Dengan pemikiran yang bebas tersebut, akan mampu melahirkan karya-karya yang sangat spektakuler dalam mengartikulasi nilai-nilai kehidupan yang penuh makna sehngga pemikiran tersebut akan membumi dan akan hidup sepanjang zaman.

Adapun metode yang penulis pakai dalam penulisan artikel ini adalah dokumentasi, di mana penulis mengumpulkan dokumen-dokumen yang berhubungan dengan rumusan masalah yang penulis angkat. Dokumen tersebut penulis dapatkan dari buku Paulo Freire yang sudah diterjemahkan, antara lain Pendidikan Sebagai Praktek Pembebasan tahun 1984 terj. Alois A. Nugroho, Politik Pendidikan: Kebudayaan, Kekuasaan dan Pembebasan tahun 2007 terj. Agung Prihantoro dan Fuad Arif Fudiyartanto dan Pendidikan Kaum Tertindas, terj. Tim Redaksi LP3ES, Cet. 7.

Kemudian data juga didapat dari buku sekunder, yaitu buku orang lain yang memuat pemikiran-pemikiran Paulo Freire dan hal-hal yang berhubungan dengannya, antara lain buku berjudul Epistimilogi Kiri karya Listiyono Santoso, Sunarto dkk., buku karya Sutrisno yang berjudul Fazlur Rahman: Kajian terhadap Metode, Epistemologi, dan Sistem Pendidikan tahun 
2006 dan buku dengann judul Paulo Freire: Kehidupan, Karya, dan Pemikirannya, terj. Henry Heyneardhi dan Anastasia P., Cet. 3 karya Denis Collins,

Selain dari buku, penulis juga merujuk pada Jurnal Tadris. Volume 2. Nomor 2 tahun 2007 karya Siswanto yang berjudul Pendidikan Sebagai Paradigma Pembebasan (Telaah Filsafat Pendidikan Paulo Freire) dan Erlina Diamastuti yang berjudul Peradigma Ilmu Pengetahuan Sebuah Telaah Kritis" dalam Jurnal Akuntansi Universitas Jember.

Setelah data-data tersebut dikumpulkan, penulis kemudian mengklasifikasikan menjadi 3 kelompok yaitu, kelompok tentang sejarah singkat Paulo Freire, Pendidikan Pembebasan Menurut Paulo Freire dan Pendidikan Pembebasan dalam Konteks PAI. Data-data yang sudah terkumpul selanjutnya diseleksi dan dimasukkan ke dalam masing-masing kelompok.

\section{Pengertian Paradigma}

Menurut KBBI, paradigma adalah model dalam teori ilmu pengetahuan atau kerangka berpikir. ${ }^{1}$ Paradigma adalah cara pandang atau perspektif seseorang dalam menghadapi permasalahan yang mendasar untuk memahami suatu ilmu dan menuntun seseorang untuk melakukan tindakan dalam kehidupan.

Capra dalam bukunya Tao of Physics menyatakan bahwa paradigma adalah asumsi dasar yang membutuhkan bukti pendukung untuk asumsi-asumsi yang ditegakkannya, dalam menggambarkan dan mewarnai interpretasinya terhadap realita sejarah sains. Sedangkan Kuhn dalam bukunya The Structure of Scientific Revolution menyatakan bahwa paradigma adalah gabungan hasil kajian yang terdiri dari seperangkat konsep, nilai, teknik dll yang digunakan secara bersama dalam suatu komunitas untuk menentukan keabsahan suatu masalah berserta solusinya. ${ }^{2}$

\section{Pengertian Pendidikan}

Istilah pendidikan berasal dari kata "didik" dengan memberikan awalan "pe" dan akhiran "an", mengandung arti "perbuatan" (hal, cara dan sebagainya)."3 Dalam Kamus Besar Bahasa Indonesia, pendidikan adalah proses pengubahan sikap dan tata laku seseorang atau kelompok orang dalam usaha mendewasakan manusia melalui upaya pengajaran dan pelatihan; proses, cara, perbuatan mendidik. "Kata pendidikan berasal dari bahasa Yunani paedogogos

\footnotetext{
1 Kamus Bahasa Indonesia, (Jakarta: Pusat Bahasa, 2008), hal. 1123.

2 Erlina Diamastuti, "Peradigma Ilmu Pengetahuan Sebuah Telaah Kritis" dalam Jurnal Akuntansi Universitas Jember, hal. 62.

${ }^{3}$ Poerwardaminta, WJS, Kamus Umum Bahasa Indonesia, (Jakarta: Balai Pustaka, 1976), hal. 250. 
yang berarti pergaulan dengan anak-anak." "Paedagog (pendidik atau ahli didik) ialah seseorang yang tugasnya membimbing anak." ${ }^{5}$

Menurut Ahmad D. Marimba dalam buku Humanitas Spiritual dalam Pendidikan bahwa "Pendidikan adalah bimbingan atau pimpinan secara sadar oleh si pendidik terhadap perkembangan jasmani dan rohani peserta didik menuju terbentuknya kepribadian yang utama. Berdasarkan rumusan ini, Marimba menyatakan ada lima unsur utama dalam pendidikan, yaitu: Usaha (kegiatan), ada pendidik, peserta didik dan tujuan pendidikan serta adanya media-media yang digunakan."

Menurut Ki Hajar Dewantoro dalam buku Dasar \& Teori Pendidikan Dunia (tantangan bagi para pemimpin pendidikan) pendidikan adalah daya upaya untuk memajukan bertumbuhnya budi pekerti, pikiran dan tubuh anak untuk memajukan kehidupan anak didik selaras dengan dunianya." "Term at-tarbiyah berakar dari tiga kata, yakni pertama, berasal dari kata rabba yarbu yang artinya bertambah dan tumbuh. Kedua, berasal dari kata rabiya yarbi yang artinya tumbuh dan berkembang. Ketiga, berasal dari kata rabba yarubbu yang artinya memperbaiki, membimbing, menguasai, memimpin, menjaga, dan memelihara." 8

Menurut Undang-Undang No. 20 tahun 2003 tentang SISDIKNAS Bab I mengatakan, pendidikan adalah usaha sadar dan terencana untuk mewujudkan suasana belajar dan proses pembelajaran agar peserta didik secara aktif mengembangkan potensi dirinya untuk memiliki kekuatan spiritual keagamaan, pengendalian diri, kepribadian, kecerdasan, akhlak mulia, serta keterampilan yang diperlukan bagi dirinya, masyarakat, bangsa dan negara." 9

Pendidikan merupakan kebutuhan pokok bagi manusia, karena manusia saat dilahirkan tidak mengetahui sesuatu apapun, sebagaimana firman Allah:

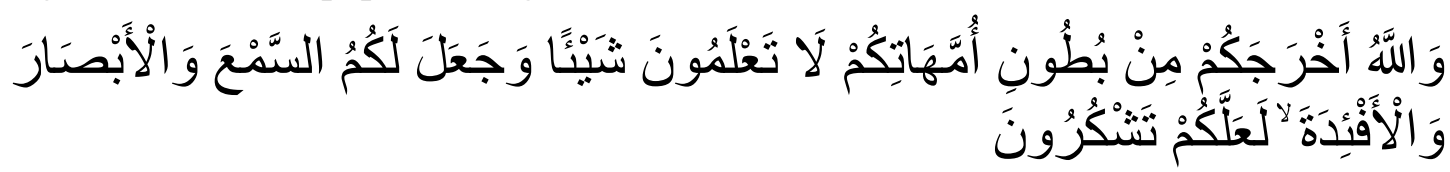

"Dan Allah mengeluarkan kamu dari perut ibumu dalam keadaan tidak mengetahui sesuatupun, dan Dia memberi kamu pendengaran, penglihatan dan hati, agar kamu bersyukur." (Q.S. An-Nahl [16]: 78)

Namun di sisi lain manusia memiliki potensi dasar (fitrah) yang harus dikembangkan sampai batas maksimal, dan untuk mengembangkan potensi tersebut diperlukan adanya

\footnotetext{
${ }^{4}$ Ramayulis, Ilmu Pendidikan Islam, (Jakarta: Kalam Mulia, 2015), hal. 30.

5 M. Ngalim Purwanto, Ilmu Pendidikan Teoritis dan Praktis, (Bandung: PT Remaja Rosdakarya, 1998),
} hal. 3 .

${ }^{6}$ Triyo Supriyatno, Humanitas Spiritual dalam Pendidikan, (Malang: UIN-Malang Press, 2009), hal. 6.

${ }^{7}$ Wasty dan Hendyat, Dasar \& Teori Pendidikan Dunia: Tantangan Bagi Para Pemimpin Pendidikan, (Surabaya: Usaha Nasional, $\mathrm{tt}$ ), hal. 11.

${ }^{8}$ Al-Raghib Al-Isfahany, Mu'jam al-Mufradat Alfazh al-Qur'an, (Beirut: Dar al Fikr, tt), hal. 189.

${ }^{9}$ UU RI No. 20 Tahun 2003, Tentang Sistem Pendidikan Nasional, (Jakarta: Sinar Grafika, 2006) 
pendidikan agar fitrah tersebut tetap berada pada garis yang semestinya dan tidak menyimpang. Sebagaimana firman Allah:

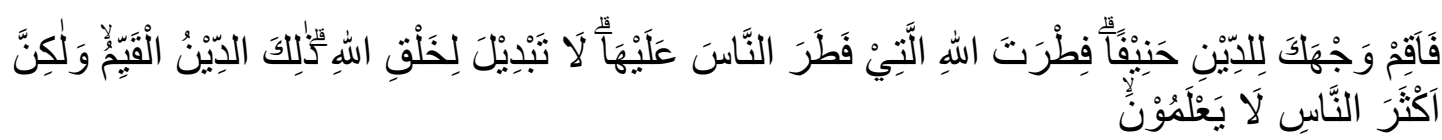

"Maka hadapkanlah wajahmu dengan Lurus kepada agama Allah; (tetaplah atas) fitrah Allah yang telah menciptakan manusia menurut fitrah itu. tidak ada peubahan pada fitrah Allah. (Itulah) agama yang lurus; tetapi kebanyakan manusia tidak mengetahui." ${ }^{10}$ (Q.S. Ar-Rum [30]: 30)

Pendidikan merupakan kebutuhan hidup manusia, bagaimana tidak meskipun manusia tersebut berada dalam suatu komunitas, pendidikan akan tetap diperlukan, hal ini sesuai dengan meningkatnya derajat orang-orang yang berilmu:

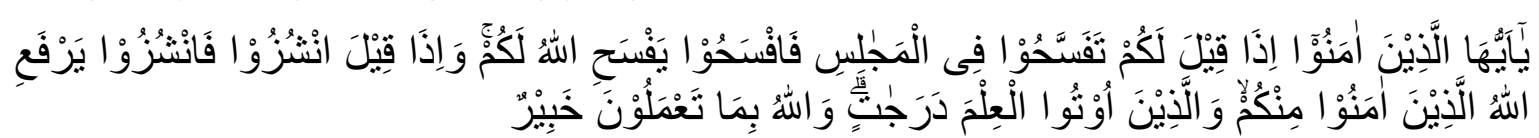

"Hai orang-orang beriman apabila kamu dikatakan kepadamu: "Berlapang-lapanglah dalam majlis", Maka lapangkanlah niscaya Allah akan memberi kelapangan untukmu. dan apabila dikatakan: "Berdirilah kamu", Maka berdirilah, niscaya Allah akan meninggikan orang-orang yang beriman di antaramu dan orang-orang yang diberi ilmu pengetahuan beberapa derajat. dan Allah Maha mengetahui apa yang kamu kerjakan.” (Q.S. AlMujaadilah [58]: 11)

\section{Pengertian Pendidikan Pembebasan}

Pembebasan itu sendiri dalam perspektif Paulo Freire berarti ketidak adanya paksaan. ${ }^{11}$ Oleh karena itu, kata lain dari bebas adlaah merdeka. Artinya tidak ada belenggu sebagai penghalang ruang gerak manusia. Sehingga dapat dipahami bahwa pendidikan pembebasan adalah "usaha sadar yang dilakukan manusia dalam mendidik manusia menjadi individu yang sadar terhadap sekelilingnya,"12 yang dari sikap merdeka tersebut akan mampu memberikan berbagai kontribusi dalam kehidupan yang sedang dijalani.

\section{Sejarah Singkat Paulo Freire}

Pemikiran Freire bertolak pada kehidupan yang dialaminya. Dunia yang dirasakan beberapa orang terasa tidak adil, adanya jeratan ketidakbebasan. Sedangkan sebagian yang lain

\footnotetext{
${ }^{10}$ Fitrah Allah: Maksudnya ciptaan Allah. manusia diciptakan Allah mempunyai naluri beragama Yaitu agama tauhid. kalau ada manusia tidak beragama tauhid, Maka hal itu tidaklah wajar. mereka tidak beragama tauhid itu hanyalah lantara pengaruh lingkungan.

11 Umiarso dan Zamroni, Pendidikan Pembebasan dalam Perspektif Barat dan Timur, Cet. 1, (Yogyakarta: Ar-Ruzz Media, 2011), hal. 52.

12 Tonny D. Widiastono, Pendidikan Manusia Indonesia, (Jakarta: Buku Kompas, 2004), hal. 5.
} 
menikmati jerih payah dari orang lain. Paulo Freire lahir pada tanggal 19 september 1921 di Recife, ${ }^{13}$ sebuah kota pelabuhan di timur laut Brazil. ${ }^{14}$ Keluarga Freire Berasal dari kelas menengah, tetapi sejak kecil dia hidup dalam situasi miskin, karena keluarganya tertimpa kemunduran finansial yang diakibatkan oleh krisis ekonomi yang melanda Amerika Serikat sekitar tahun 1929 dan juga menular ke Brazil. Dari situasi inilah Freire menemukan dirinya sebagai bagian dari "kaum rombeng dari bumi". ${ }^{15}$

Keadaan tersebut menimbulkan pengaruh yang sangat kuat dalam kehidupan dan perjuangannya, sehingga Freire sangat menyadari apa artinya lapar bagi anak-anak sekolah dasar. Keluarga Freire kemudian pindah ke Jabotao pada tahun 1931 dan di sanalah kemudian ayahnya meninggal. "Prof. Richard Shaull, menceritakan bahwa pada tahap ini Freire memutuskan untuk mengabdikan hidupnya pada perjuangan melawan kelaparan, sehingga tidak ada anak lain yang merasakan penderitaan yang ia alami”. ${ }^{16}$

Ia juga bekerja paruh waktu sebagai instruktur bahasa portugis di sekolah lanjutan, dan seperti kebanyakan remaja, ia mulai mempertanyakan ketidaksesuaian yang ada antara khotbah yang didengarnya di Gereja dengan kenyataan kehidupan sehari-hari. ${ }^{17}$ Pada awal tahunn 1960-an, Brazil mengalami masa-masa sulit. Gerakan-gerakan reformasi baik dari kalangan sosialis, komunis, pelajar, buruh, maupun militan Kristen, semuanya mendesakkan tujuan sosial politik mereka masing-masing. "Waktu itu Brazil mempunyai penduduk sekitar 34,5 juta jiwa dan hanya 15,5 juta yang hanya dapat ikut pemilihan umum". ${ }^{18}$ Hak ikut serta dalam pemilihan umun di Brazil pada saat itu dikaitkan dengan kemampuan seseorang dalam menuliskan nama masing-masing. Sehingga tidak mengherankan jika "program kenal aksara kerap sekali dikaitkan dengan usaha peningkatan kesadaran politik penduduk, terlebih penduduk pedalaman yang telah lama menjadi alat untuk mendukung kepentingan-kepentingan golongan minoritas yang berkuasa." 19

\footnotetext{
${ }^{13}$ Recife merupakan pusat salah satu daerah paling miskin dan terbelakang di dunia ketiga, lihat kata pengantar Richard Shaull dalam Paulo Freire, Pendidikan Kaum Tertindas, terj. Tim Redaksi LP3ES, Cet. 7, (Jakarta: LP3ES, 2011), hal. x.

${ }^{14}$ Listiyono Santoso, Sunarto dkk., Epistimilogi Kiri, Cet. 1, (Yogyakarta: Ar-Ruzz, 2003), hal. 126. Lihat juga Denis Collins, Paulo Freire: Kehidupan, Karya, dan Pemikirannya, terj. Henry Heyneardhi dan Anastasia P., Cet. 3, (Yogyakarta: Pustaka Pelajar kerjasama dengan Komunitas APIRU Yogyakarta, 2011), hal. 6 .

${ }^{15}$ Paulo Freire, Pendidikan Sebagai Praktek Pembebasan, Penerjemah: Alois A. Nugroho, (Jakarta: PT Gramedia, 1984), hal. 157.

${ }^{16}$ Denis Collins, Paulo Freire: Kehidupan, Karya, dan Pemikirannya..., hal. 6-7.

${ }^{17}$ Denis Collins, Paulo Freire: Kehidupan, Karya, dan Pemikirannya..., hal. 6-7.

18 Paulo Freire, Pendidikan Kaum Tertindas..., hal. xii.

${ }^{19}$ Paulo Freire, Pendidikan Kaum Tertindas..., hal. xii.
} 
Dalam suasana seperti ini, Freire kemudian menjabat sebagai direktur Cultural Extention Service yang pertama di Universitas of Recife yang pada masanya melaksanakan program pemberantasan buta huruf kepada ribuan petani miskin di timur laut. Metode yang dipakai kemudian dikenal dengan "Metode Paulo Freire, meskipun dia sendiri tidak pernah menamakan metodenya dengan sebutan seperti itu." 20

\section{Pendidikan Pembebasan Menurut Paulo Freire}

Kritik pertama dilontarkan bukan langsung tertuju kepada guru, namun lebih ke sistem pendidikan yang memberikan makna yang berbeda tentang hakikat guru dan murid. Sistem pendidikan sepertinya telah memanipulasi kedudukan guru dari yang seharusnya. Guru menjadi pihak yang aktif dan murid menjadi pihak yang pasif dan akan mejadi pasif seterusya.

Tidaklah penting apakah guru menyadari bahwa pendidikan itu membelenggu atau tidak, karena intinya terletak pada manipulasi kedudukan guru dan siswa, di mana siswa dibuat menjadi objek pasif dari tindakan guru. Sebagai pihak yang pasif, siswa tidak dituntut untuk berpartisipasi aktif dalam proses belajar, karena siswa hanya diisi dengan kata-kata oleh guru. ${ }^{21}$

Guru juga bukan sebagai subjek yang hanya bertugas memberi ilmu kepada murid, lebih dari itu, guru adalah mitra murid dalam mengembangkan daya kritis, membantu murid dalam mengeksplor pengetahuannya, memancing imajinasi murid sehingga, murid mampu menyampaikan apa yang menjadi sudut pandangnya.

Dalam kerangka budaya pendidikan ini, guru mengajarkan kepada siswa seolah-olah dirinya terpisah dari kehidupan nyata, seolah-olah bahasa-pemikiran itu bisa muncul tanpa kenyataan yang ada. Dalam praktik pendidikan seperti ini, struktur sosial tidak pernah didiskusikan karena tidak dianggap sebagai masalah yang perlu dipecahkan. Sebaliknya, struktur sosial tersebut justru dibuat menjadi tidak jelas dengan berbagai cara yang mengakibatkan siswa memiliki kesadaran yang 'salah'. ${ }^{22}$

Sebenarnya, pendidikan merupakan miniatur dari kehidupan, jadi seharusnya apa yang dijarkan guru adalah hal-hal yang berhubungan dengan kehidupan murid. Bukan malah memisahkan keduanya. Seperti halnya pendidikan struktur sosial, pendidikan ini sangat urgen karena dapat menyadarkan murid tentang eksistensi seseorang dalam masyarakat, agar murid tahu bagaimana seharusnya dia bertindak, memposisikan diri dan menyadarkan murid bahwa ia adalah bagian dari masyarakat yang diharapkan memberikan perubahan ke arah yang lebih baik.

\footnotetext{
20 Paulo Freire, Pendidikan Kaum Tertindas..., hal. xiii.

${ }^{21}$ Paulo Freire, Politik Pendidikan: Kebudayaan, Kekuasaan dan Pembebasan, terj. Agung Prihantoro dan Fuad Arif Fudiyartanto, (Yogyakarta: Pustaka Pelajar, 2007), hal. 175.

22 Paulo Freire, Politik Pendidikan: Kebudayaan, hal.175
} 
Guru juga seharusnya mengikuti perkembangan murid, misal memakai bahasa murid, bukan hanya bahasa linguistik saja, namun budaya dan konteks hidup yang sedang muridmurid hadapi, sehingga murid mudah mengerti apa yang dimaksud oleh guru tersebut.

Kunci pendidikan terletak pada proses dialog antara guru dan murid. 2 arah yang saling memberikan timbal balik, sehingga tidak terjadi kematian dalam berpikir. Proses dialog juga akan meningkatkan daya kritis dan kemampuan mentransformasi ilmu-ilmu dalam sekolah kepada lingkungan tempat ia tinggal serta yang paling penting adalah murid dapat menyelesaikan problematika yang tengah ia hadapi.

Empat kali empat sama dengan enam belas, ibu kota Para adalah Belem”. Muridmurid mencatat, menghafal dan mengulangi ungkapan-ungkapan tersebut tanpa memahami apa arti sesungguhnya dari empat kali empat, atau tanpa menyadari makna sesungguhnya dari kata "ibu kota" dalam ungkapan "ibu kota Para adalah Belem”, yakni apa arti Belem bagi Para dan apa arti Para bagi Brasil. ${ }^{23}$

Hal tersebut juga terjadi di pendidikan Indonesia. Murid hanya dicekoki berbagai materi tanpa penjelasan dari guru apa hakikat, maksud, tujuan murid mempelajari hal tersebut. Pendidikan tersebut diistilahkan oleh Paulo Freire sebagai pendidikan bercerita.

Pendidikan bercerita - dengan guru sebagai pencerita - mengarahkan murid-murid untuk menghafal secara mekanis apa isi pelajaran yang diceritakan. Lebih buruk lagi, murid diubahnya menjadi "bejana-bejana", wadah-wadah kosong untuk diisi oleh guru. Semakin penuh dia mengisi wadah itu, semakin baik pulaseorang guru. Semakin patuh wadah-wadah ituuntuk diisi semakin baik pula mereka sebagai murid. $^{24}$

Yang terjadi bukanlah proses komunikasi, tetapi guru menyampaikan penyataanpernyataan dan "mengisi tabungan" yang diterima, dihafal dan diulang dengan patuh oleh para murid. Inilah konsep pendidikan "gaya bank", di mana ruang gerak yang disediakan bagi kegiatan para murid hanya terbatas pada menerima, mencatat dan menyimpan. ${ }^{25}$

Paulo Freire mengkritik tajam sistem pendidikan gaya bank dimana pendidikan seakanseakan seperti proses menabung. Guru sebagai nasabah dan murid sebagai brankas - tempat untuk menyimpan uang - dalam hal ini uang diposisikan sebagai ilmu yang diletakkan di brankas tersebut. Materi-materi yang harusnya dapat memancing daya kritis, malah menjadi beban untuk murid, menjadikan murid seperti mesin mekanis yang mengharuskan materi

\footnotetext{
${ }^{23}$ Paulo Freire, Pendidikan Kaum Tertindas..., hal. 52.

${ }^{24}$ Paulo Freire, Pendidikan Kaum Tertindas..., hal. 52

${ }^{25}$ Paulo Freire, Pendidikan Kaum Tertindas..., hal. 52
} 
dihafal secara leterlek tanpa memberi kesempatan untuk mengembangkan dan memberikan pendapat menurut sudut pandangnya.

Pendidikan gaya bank memiliki kebiasaan-kebiasaan berikut, yang mencerminkan suatu keadaan masyarakat tertindas secara keseluruhan:

1. Guru mengajar, murid

2. Guru mengetahui segala sesuatu, murid tidak tahu apa-apa

3. Guru berpikir, murid dipikirkan

4. Guru bercerita, murid patuh mendengarkan

5. Guru menentukan peraturan, murid diatur

6. Guru memilih dan memaksakan pilihannya, murid menyetujui

7. Guru berbuat, murid membayangkan dirinya berbuat melalui perbuatan gurunya

8. Guru memilih bahan dan isi pelajaran, murid (tanpa diminta pendapatnya) menyesuaikan diri dengan pelajaran itu

9. Guru mencampuradukkan kewenangan ilmu pengetahuan dan kewenangan jabatannya, yang dia lakukan untuk menghalangi kebebasan murid

10. Guru adalah subyek dalam proses belajar, murid adalah obyek belaka. ${ }^{26}$

Dari penjelasan di atas, dapat disimpulkan bahwa guru menjadi sosok sentral, prototipe yang harus diikuti oleh murid. Hal ini akan mematikan proses berfikir kritis, membekukan daya kreatif, mengurangi keterlibatannya, sehingga murid menjadi mudah percaya dan menumbuhkan sifat manja.

Sangat disayangkan jika pendidikan memposisikan murid sebagai sesuatu yang mati, yang hanya bertugas menerima apa yang diberikan. Jika dianalogikan seperti seseorang mengisi berliter-liter air ke tangki kosong tanpa tangki mengetahui untuk apa air-air tersebut. Padahal murid juga merupakan manusia yang memiliki segudang kemampuan yang berbedabeda. Memiliki bakat yang luar biasa. Mampu berpikir kritis dan dapat mengampaiakan segala bentuk dengan sudut pandangnya. Tugas guru adalah melatih dan menemukan hal-hal yang tersembunyi, digali sehingga dapat menghasilkan murid yang hebat sesuai dengan bidangnya.

\section{Hakikat Belajar Menurut Paulo Freire}

Lain halnya dengan visi pendidikan yang kritis: seorang pembaca merasa tertantang oleh teks yang disajikankan padanya dan tujuan membaca adalah untuk memahami (appropriate) makna yang lebih dalam. ${ }^{27}$

Menurut Paulo Freire, membaca dan belajar tidak hanya sekedar menghafal tanpa mengetahui maknanya. Namun ada esensi yang lebih penting yakni memahami konteks yang sedang ia baca. Kefokusan dalam membaca benar-benar dibutuhkan, agar tidak hanya bersifat mekanis seperti yang digambarkan Paulo Freire, yang mana pembaca tidak memfokuskan diri

${ }^{26}$ Paulo Freire, Pendidikan Kaum Tertindas..., hal. 54

${ }^{27}$ Paulo Freire, Politik Pendidikan: Kebudayaan, Kekuasaan dan Pembebasan..., hal. 29. 
pada buku yang dibacanya, namun justru memikirkan hal yang lainnya. Berbeda dengan murid yang diajarkan berpikir kritis, pembaca akan merasa tertantang oleh teks yang disajikan dan dituntut untuk memahami apa yang sedang dibicarakan dalam buku tersebut.

Berbicara tentang pengembangan daya kritis murid, Paulo Freire memberikan beberapa cara untuk mengembangkan aspek tersebut, diantaranya:

1. Pembaca harus mengetahui peran dirinya

Mempelajari sebuah teks secara serius memerlukan analisa terhadap sebuah bidang kajian yang ditulis oleh orang yang mempelajarinya. Ini juga memerlukan pemahaman terhadap sosio-historis ilmu pengetahuan. Selain itu, pun perlu meneliti isi teks tersebut dan mempelajari pengetahuan-pengetahuan yang lain. Belajar adalah sebuah bentuk penemuan kembali (reinventing), menciptakan kembali (recreating), penulisan ulang (rewriting). ${ }^{28}$

Akhir dari kegiatan belajar yaitu adanya daya cipta, menginovasikan sesuatu yang sudah ada. Seperti istilah ATM yang merupakan singkatan dari Amati, Tulis dan Modifikasi. Istilah tersebut dirasa sangat berhubungan dengan teori Paulo Freire tentang makna belajar.

Sikap kritis dalam belajar sama dengan sikap yang diperlukan untuk menghadapi dunia (yakni dunia dan kehidupan nyata pada umumnya), untuk bertanya dalam hati, yang dimulai dengan terus mengamati kebenaran yang tersembunyi di balik fakta yang dipaparkan dalam teks-teks. ${ }^{29}$

Sewaktu membaca sebuah teks, kita sebagai subjek harus merefleksikan (merenungkan) setiap topik pembicaraan, walaupun bukan merupakan tema utama teks (buku) tersebut. Dengan merenungkannya yang berarti menghubungkan antara tulisan yang kita baca dan pengetahuan yang telah kita miliki sebelumnya, maka sebagai pembaca yang baik kita seharusnya menganalisa teks tersebut, mencari hubungan antara gagasan utama teks tersebut dengan tujuan (kepentingan) membaca. Namun demikian, ada sebuah syarat yang perlu diperhatikan: kita harus menganalisa isi teks dengan cara mengingat apa yang telah kita ketahui sebelum membaca teks tersebut atau sesudahnya, supaya kita tidak dianggap mengkhianati pemikiran utuh penulis. ${ }^{30}$

Dalam analisa terakhir, mempelajari sebuah teks dengan serius, laiknya mempelajari sebuah artikel, mensyaratkan bukan hanya pengamatan yang kritis terhadap isi pokok tetapi juga pengamatan terhadap kepekaan, ketenangan intelektual yang mantap, dan keinginan untuk meneliti. ${ }^{31}$

Paulo Freire juga sangat menekankan arti belajar kritis, karena sikap kritis tersebut yang akan diperlukan dalam kehidupan sehari-hari. Pengetahuan yang dimiliki kemudian diintegrasikan dengan kehdiupan yang sedang ia hadapi. Pengetahuan-pengetahuan tersebut

\footnotetext{
${ }^{28}$ Paulo Freire, Politik Pendidikan: Kebudayaan, hal.29

${ }^{29}$ Paulo Freire, Politik Pendidikan: Kebudayaan, hal.30

${ }^{30}$ Paulo Freire, Politik Pendidikan: Kebudayaan, hal.30

${ }^{31}$ Paulo Freire, Politik Pendidikan: Kebudayaan, hal.31
} 
pastilah di dapat dari membaca. Hal tersebut sebagai jawaban mengapa Paulo Freire kembali menuliskan betapa pentingnya konsentrasi dan sikap kritis dalam membaca sebuah buku.

2. Pada dasarnya praktik belajar adalah bersikap terhadap dunia

Sebenarnya sebuah teks merupakan refleksi dan mengekspresikan pergulatan penuls dengan dunia. Dan bahkan ketika seorang penulis tidak begitu menaruh perhatian terhadap kenyataan yang sesungguhnya, dia akan tetap mengekspresikan bagaimana dia berseteru dengan dunia. Dengan demikian, belajar adalah memikirkan pengalaman, dan memikirkan pengalaman adalah cara terbaik untuk berpikir secara benar. Orang yang sedang belajar tidak boleh menghentikan rasa ingin tahunya terhadap orang lain dan kehidupan nyata. Mereka itu selalu bertanya dan berusaha menemukan jawaban, serta terus mencarinya. ${ }^{32}$

Teks merupakan hasil dari pemikiran penulisnya yang merupakan ekspresi dari penilaian penulis terhadap dunia. Belajar merupakan jalan memilih pengalaman, sebelum memilih terhadap apa yang akan dilakukan merupakan cara berpikir yang benar. Rasa ingin tahu yang semakin besar merupakan hakikat seorang pelajar, tidak malu bertanya serta terus mencari jawaban dari rasa ingin tahunya. Dari hasil berpikir, dia akan melakukan sesuatu yang akan menjadi pengalamannya, dan hal-hal tersebut merupakan proses belajar untuk menyiapkan diri menghadapi dunia.

3. Kapan saja mempelajari sesuatu kita dituntut menjadi lebih akrab dengan bibliografi yang telah kita baca, dan juga bidang studi secara umum atau bidang studi yang kita alami.

4. Perilaku belajar mengasumsikan hubungan dialektis antar pembaca dan penulis yang refleksinya dapat ditemukan dalam tema teks tersebut

5. Perilaku belajar menuntut rasa rendah hati (sense of modesty) ${ }^{33}$

Jika kita benar-benar mempunyai sikap rendah hati dan kritis, kita tidak perlu merasa bodoh sewaktu kita dihadapkan pada kesulitan yang besar untuk memahami makna sebenarnya dari suatu teks. Teks yang kita baca tidak selalu mudah untuk dipahami. "Dengan sikap rendah hati dan kritis kita lantas mengetahui bahwa teks tersebut bisa jadi berada di luar kemampuan kita untuk memahaminya, sehingga teks itu menjadi sebuah tantangan tersendiri." 34

Kualitas perilaku belajar (the act of study) tidak bisa diukur dengan jumlah halaman yang dibaca selama satu malam atau jumlah buku yang dibaca selama satu semester.

\footnotetext{
32 Paulo Freire, Politik Pendidikan: Kebudayaan, hal.32

${ }^{33}$ Paulo Freire, Politik Pendidikan: Kebudayaan, Kekuasaan dan Pembebasan..., hal. 32.

${ }^{34}$ Paulo Freire, Politik Pendidikan: Kebudayaan, hal.33
} 
Belajar bukanlah mengkonsumsi ide, namun menciptakan dan terus menciptakan ide. ${ }^{35}$

Tanpa disadari, saat membaca sebuah buku, pembaca melakukan diskusi-komunikasi secara tidak langsung dengan penulis. Itulah mengapa pembaca dituntut lebih akrab dengan bibliografi. Tema yang dibaca merupakan bahan perbincangan dialektis antara pembaca dan penulis.

Sifat rendah hati mengajarkan untuk tidak merasa bodoh saat membaca teks di luar kemampuan pembaca. Menghadirkan sikap kritis dan rendah hati akan mampu menyadarkan pembaca bahwa teks tersebut merupakan tantangan baru yang harus ditaklukkan, meskipun Paulo Freire sendiri menyatakan bahwa belajar sesungguhnya bukanlah dilihat dari jumlah halaman yang telah dibaca. Lebih dari itu, tujuan utama belajar adalah menghasilkan daya cipta secara kontinu.

Sebenarnya, sepanjang pendidikan dibatasi hanya pada metode dan teknik pengajaran bagi anak didik, sedangkan guru dalam mencermati realitas sosial - jika mereka benar-benar mau melakukannya - tidak lebih dari sekedar mendeskripsikannya maka tujuan pendidikan semacam ini sangat terbatas. Pendidikan untuk kebebasan ini tidak sekedar dengan menggunakan proyektor dan kecanggihan sarana teknologi lainnya yang ditawarkan sesuatu kepada peserta didik yang berasal dari latar belakang apapun. Namun "sebagai sebuah praksis sosial, pendidikan berupaya memberikan bantuan untuk membebaskan manusia di dalam kehidupan objektif dari penindasan yang mencekik mereka." ${ }^{36}$

Pendidikan pembebasan menurut Paulo Freire tidak sekedar menuntut metode, alat, teknik mengajar dengan mencermati relaita sosial. Jika hal itu saja yang diterapkan oleh guru, maka sama saja murid tidak mengalami kebebasan berpikir dan berekspresi. Oleh karena itu sebagai praksis sosial, pendidikan haruslah berusaha memberikan kebebasan dari jeratan yang selama ini dialaminya.

\section{Pendidikan Pembebasan dalam Konteks Pendidikan Agama Islam (PAI)}

Pendidikan Agama Islam (PAI) merupakan salah satu materi yang harus disampaikan kepada murid khususnya yang beragama Islam. Penyampaiannya pun hampir sama dengan prinsip pendidikan yang ditawarkan Paulo Freire, hanya saja kebebasan berpikir maupun bertindak murid memiliki batas yang harus dibenarkan oleh dalil Naqli, yaitu Alquran dan Hadis karena keduanya merupakan pedoman umat Islam dalam menjalankan kehidupan.

\footnotetext{
${ }^{35}$ Paulo Freire, Politik Pendidikan: Kebudayaan, hal.32

${ }^{36}$ Paulo Freire, Politik Pendidikan: Kebudayaan, hal.208
} 
Pendidikan pembebasan dalam konteks PAI mengharuskan materi PAI disampaikan untuk menjawab tantangan zaman dan tetap berdasarkan kebutuhan atau masalah murid, oleh karena itu, pengetahuan agama yang diperoleh dapat diterapkan di kehidupan sehari-hari. Teori double movement oleh Fazlur Rahman juga memuat karakteristik pendidikan agama Islam based on problem ini.

Suatu gerakan ganda, gerakan dari situasi sekarang ke masa Alquran diturunkan, kemudian gerakan kembali ke masa datang. Metode ini bisa dilakukan dengan (1) membawa problem-problem umat (sosial) untuk dicarikan solusinya pada Alquran atau (2) memaknai Alquran dalam konteksnya dan memproyeksikannya kepada situasi sekarang. ${ }^{37}$

Hal lain yang sangat diperlukan adalah pengembangan sikap kreativitas, yakni suatu sikap untuk memilih dan memilah informasi yang tepat, saling menyebarkan informasi dalam suatu networking atau rangkaian sehingga terciptalah berbagai ide-ide baru. Kemampuan untuk menciptakan sesuatu yang baru dari lautan informasi yang ada merupakan sesuatu yang perlu dikembangkan di dalam sistem pendidikan. Di samping itu, "siswa dapat melakukan refleksi pemikiran untuk melakukan berbagai perubahan dengan perubahan-perubahan komprehensif sebagai respon terhadap perubahan dunia yang sedang terjadi, dan atau hasil analisis prediktif yang dilakukan secara seksama dan cermat serta holistik." 38

Apabila murid dilatih untuk aktif, kritis, kreatif dan dialogis, maka kelas akan hidup. Saling membagi pengalaman membaca, peristiwa hidup maupun problematika yang sedang dihadapi yang nantinya akan dikaitkan dengan Alquran dan Hadis. Ataupun mengkaji Alquran dan Hadis dan memproyeksikan dengan hal-hal yang terjadi dewasa ini. Hal ini sesuai dengan pemikiran Paulo Freire bahwa pendidikan harus ada kaitannya dengan apa yang dialami murid, sehingga murid mengetahui sesungguhnya hakikat belajar.

\section{Kesimpulan}

Pembangunan kesadaran akan relevansi pendidikan dengan kehidupan harus dibangun diawal pembelajaran, agar murid mengetahui mengapa harus mempelajari tema-tema yang tertera di buku. Penyampaiannya pun mestinya disesuaikan dengan kondisi murid, mulai dari bahasa sampai materi-materi yang akan disampaikan, sehingga murid mudah menyerap ilmu yang dipelajari.

37 Sutrisno, Fazlur Rahman: Kajian terhadap Metode, Epistemologi, dan Sistem Pendidikan, (Yogyakarta: Pustaka Pelajar, 2006), hal. 133-134.

38 Siswanto, "Pendidikan Sebagai Paradigma Pembebasan (Telaah Filsafat Pendidikan Pulo Freire)" dalam Jurnal Tadris, Vol. 2 Nomor 2, 2007, hal. 261. 
Pendidikan bukan proses bercerita, bukan pula seperti gaya bank. Murid juga sebagai manusia yang berhak memilliki kebebasan berekspresi dan mengemukakan pendapat. Apabila murid hanya dicekoki materi-materi tanpa diberi kesempatan untuk menyampaikan pendapatnya, tidak ada proses dialog di dalamnya, maka lambat laun pendidikan mernjadi suatu proses yang mematikan daya pikir.

Proses berpikir kreatif juga ditekankan oleh Paulo Freire, karena dengan konsentrasi membaca, murid merasa tertantang oleh teks yang di sajikan, murid menjadi tahu peran dirinya sebagai seorang pembaca, karena esensi membaca dan belajar sesungguhnya adalah menemukan kembali, menciptakan kembali dan menuliskan kembali tentang apa-apa yang pernah ia baca. Dan hal itu bisa tercapai dengan mengerahkan fokus dan daya kritis saat membaca sebuah teks. Membaca juga diibaratkan sebagai proses dialog tak langsung dengan penulis buku dengan tema yang disajikan sebagai bahan dialektika. Kemudian Pendidikan pembebasan dalam konteks PAI mengharuskan materi PAI disampaikan untuk menjawab tantangan zaman dan tetap berdasarkan kebutuhan atau masalah murid, oleh karena itu, pengetahuan agama yang diperoleh dapat diterapkan di kehidupan sehari-hari. Teori double movement oleh Fazlur Rahman juga memuat karakteristik pendidikan agama Islam based on problem ini. Apabila murid dilatih untuk aktif, kritis dan dialogis, maka kelas akan hidup. Saling membagi pengalaman membaca, peristiwa hidup maupun problematika yang sedang dihadapi yang nantinya akan dikaitkan dengan Alquran dan Hadis. Ataupun mengkaji Alquran dan Hadis dan memproyeksikan dengan hal-hal yang terjadi dewasa ini. Hal ini sesuai dengan pemikiran Paulo Freire bahwa pendidikan harus ada kaitannya dengan apa yang dialami murid, sehingga murid mengetahui sesungguhnya hakikat belajar. 


\section{Daftar Pustaka}

Collins, Denis, Paulo Freire: Kehidupan, Karya, dan Pemikirannya, terj. Henry Heyneardhi dan Anastasia P., Cet. 3, Yogyakarta: Pustaka Pelajar kerjasama dengan Komunitas APIRU Yogyakarta, 2011.

Diamastuti, Erlina, "Peradigma Ilmu Pengetahuan Sebuah Telaah Kritis" dalam Jurnal Akuntansi Universitas Jember, tt.

Freire Paulo, Pendidikan Sebagai Praktek Pembebasan, terj. Alois A. Nugroho, PT Jakarta: Gramedia, 1984.

Freire, Paulo, Pendidikan Kaum Tertindas, terj. Tim Redaksi LP3ES, Cet. 7, Jakarta: LP3ES, 2011

Freire, Paulo, Politik Pendidikan: Kebudayaan, Kekuasaan dan Pembebasan, terj. Agung Prihantoro dan Fuad Arif Fudiyartanto, Yogyakarta: Pustaka Pelajar, 2007.

Al-Isfahany, Al-Raghib, Mu'jam al-Mufradat Alfazh al-Qur'an, Beirut: Dar al Fikr, tt.

Kamus Bahasa Indonesia, Departemen Pendidikan Nasional. Jakarta: Pusat Bahasa, 2008.

Kamus Umum Bahasa Indonesia, Poerwardaminta, WJS. Jakarta: Balai Pustaka, 1976.

Purwanto, M. Ngalim, Ilmu Pendidikan Teoritis dan Praktis, Bandung: PT Remaja Rosdakarya, 1998.

Ramayulis, Ilmu Pendidikan Islam, Jakarta: Kalam Mulia, 2015.

Siswanto, "Pendidikan Sebagai Paradigma Pembebasan (Telaah Filsafat Pendidikan Pulo Freire)" dalam Jurnal Tadris, Vol. 2 Nomor 2, 2007.

Sunarto, Listiyono Santoso, dkk., Epistimilogi Kiri, Cet. 1, Yogyakarta: Ar-Ruzz, 2003.

Supriyatno, Triyo, Humanitas Spiritual dalam Pendidikan, Malang: UIN-Malang Press, 2009.

Sutrisno, Fazlur Rahman. Kajian terhadap Metode, Epistemologi, dan Sistem Pendidikan, Yogyakarta: Pustaka Pelajar, 2006

Umiarso dan Zamroni, Pendidikan Pembebasan dalam Perspektif Barat dan Timur, Cet. 2, Yogyakarta: Ar-Ruzz Media, 2011.

UU RI No. 20 Tahun 2003, Tentang Sistem Pendidikan Nasional, Jakarta: Sinar Grafika, 2006.

Wasty dan Hendyat, Dasar \& Teori Pendidikan Dunia: Tantangan Bagi Para Pemimpin Pendidikan, Surabaya: Usaha Nasional, tt.

Widiastono, Tonny D., Pendidikan Manusia Indonesia, Jakarta: Buku Kompas, 2004. 